
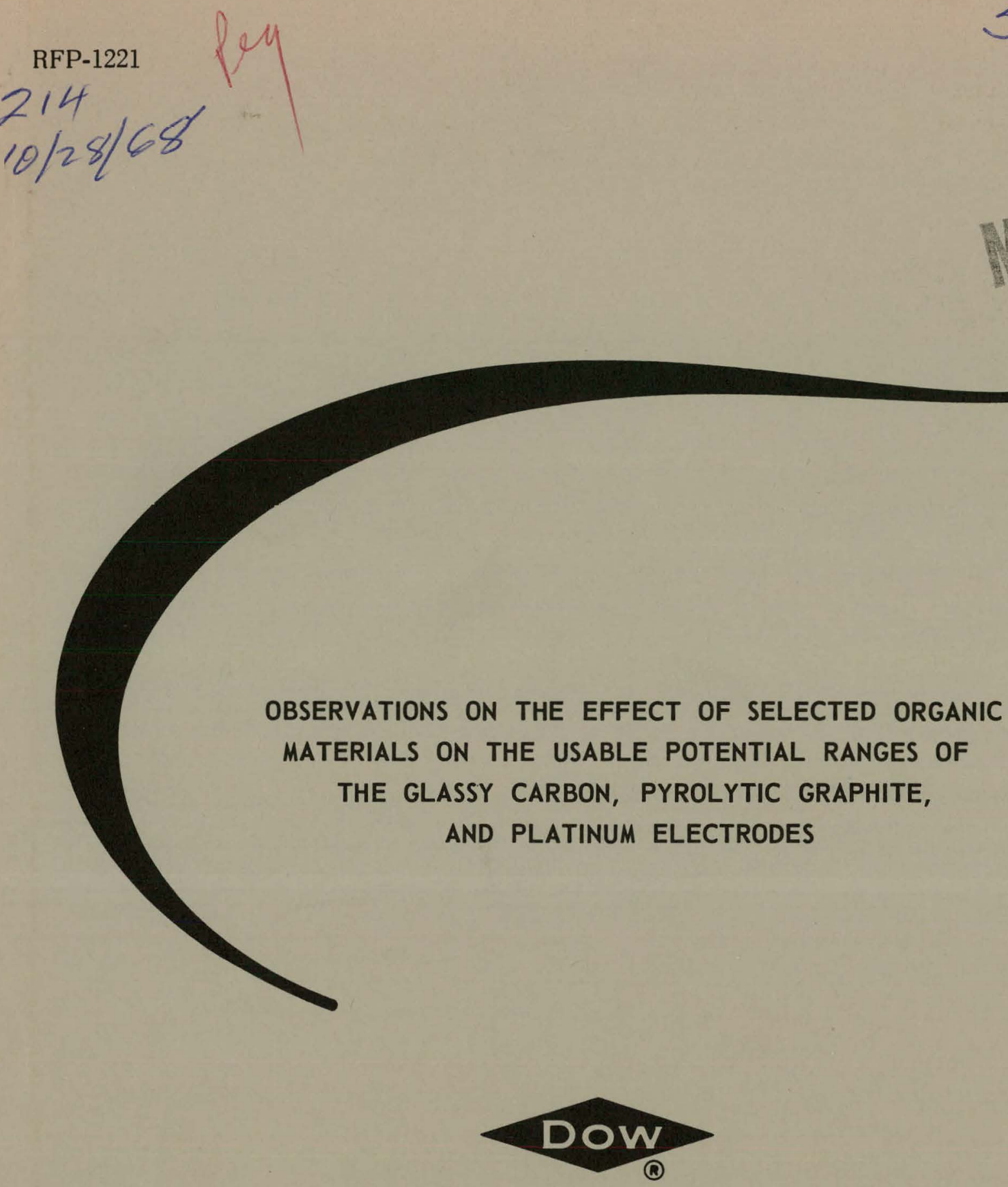

THE DOW CHEMICAL COMPANY ROCKY FLATS DIVISION

P. O. BOX 888

GOLDEN, COLORADO 80401

U.S. ATOMIC ENERGY COMMISSION CONTRACT AT(29-1)-1106 


\section{DISCLAIMER}

This report was prepared as an account of work sponsored by an agency of the United States Government. Neither the United States Government nor any agency Thereof, nor any of their employees, makes any warranty, express or implied, or assumes any legal liability or responsibility for the accuracy, completeness, or usefulness of any information, apparatus, product, or process disclosed, or represents that its use would not infringe privately owned rights. Reference herein to any specific commercial product, process, or service by trade name, trademark, manufacturer, or otherwise does not necessarily constitute or imply its endorsement, recommendation, or favoring by the United States Government or any agency thereof. The views and opinions of authors expressed herein do not necessarily state or reflect those of the United States Government or any agency thereof. 


\section{DISCLAIMER}

Portions of this document may be illegible in electronic image products. Images are produced from the best available original document. 


\section{LEG A L NOTICE}

This report was preparcd as an account of Government sponsored work. Neither the United States, nor the Commission, nor any person acting on behalf of the Commission:

A. Makes any warranty or representation, expressed or implied, with respect to the accuracy, completeness, or usefulness of the information contained in this report, or that the use of any information, apparatus, method, or process disclosed in this report may not infringe privately owned rights; or

B. Assumes any liabilities with respect to the use of, or for damages resulting from the use of any information, apparatus, method, or process disclosed in this report.

As used in the above, "person acting on behalf of the Commission" includes any employee or contractor of the Commission, or employee of such contractor, to the extent that such employee or contractor of the Commission, or employee of such contractor prepares, disseminates, or provides access to, any information pursuant to his employment or contract with the Commission, or his employment with such contractor.

Printed in the United States of America

Available from

Clearinghouse for Federal Scientific and Technical Information

National Bureau of Standards, IJ. S. Department of Commerce

Springfield, Virginia 22151

Price: Printed Copy $\$ 3.00$; Microfiche $\$ 0.65$ 


\title{
OBSERVATIONS ON THE EFFECT OF SELECTED ORGANIC MATERIALS ON THE USABLE POTENTIAL RANGES OF THE GLASSY CARBON, PYROLYTIC GRAPHITE, AND PLATINUM ELECTRODES
}

\author{
Carl E. Plock
}

\section{LEGAL NÖTICE}

This report was prepared as an account of Government sponsored work. Nelther the United States, nor the Commission, nor any person acting on behslf of the Commission:

A. Makes any warranty or representation, expressed or implied, with respect to the accuracy, completeness, or usefulness of the information contalned in this report, or that the use of any information, apparatus, method, or procese disclosed in thls report may not infringe privately owned rights; or

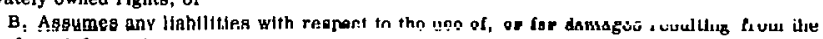
use of any information, apparatus, method, or process disclosed in this report.

As used in the above, "person acting on behalf of the commission" includes any employee or contractor of the Commission, or employee of such contractor, to the extent that such employee or contractor of the Commission, or employee of such contractor prepares, disseminates, or provides access to. any information pursuant to his employment or contract with the Commisston, or his employment with such contractor.

\footnotetext{
THE DOW CHEMICAL COMPANY ROCKY FLATS DIVISION

P. O. BOX 888

GOLDEN, COLORADO 80401

U. S. ATOMIC ENERGY COMMISSION CONTRACT AT(29-1)-1106
} 


\section{Observations on the Effect of Selected Organic Materials on the Usable Potential Ranges of the Glassy Carbon, Pyrolytic Graphite, and Platinum Electrodes}

Carl E. Plock

Abstract. The effect of several organic materials on the usable potential ranges of the glassy carbon, pyrolytic graphite, and platinum wire electrodes is reported.

\section{INTRODUCTION}

Beilby et al. (1), found the usable potential range of the pyrolytic graphite electrode in $0.5 \mathrm{M}$ potassium chloride to be +1.3 to -1.6 volts versus saturated calomel electrode. The usable potential range of the glassy carbon electrode in acid media was determined as +1.2 to -0.8 volts versus saturated ealomel electrode by Zittel and Miller (2).

During the investigation of neptunium (VI) complexes at the glassy carbon electrode and at the pyrolytic graphite electrode (3-6), it was apparent that the ligand and the $\mathrm{pH}$ of the solution were influencing the usable potential ranges of these electrodes. It was therefore decided to determine the usable potential ranges of these electrodes and, in addition, a platinum wire electrode, in a number of organic materials.

\section{SUMMARY}

The effect of disodium malonate, disodium glutamate, sodium glycinate, disodium succinate, trisodium nitriloacetate, tetrasodium ethylenediaminetetraacetate, disodium iminodiacetate, sodium lastate, triethanolamine, 1,3-propanediamine, diisopropylamine and trisodium citrate at various $\mathrm{pH}$. values on the usable potential ranges of the glassy carbon electrode, pyrolytic graphite electrode, and a platinum wire electrode has been tabulated.

\section{EXPERIMENTAL}

Apparatus: All voltammograms were obtained at $25^{\circ} \mathrm{C}$ with a Sargent Model XV recording polarograph. The electrolysis cell $(3,7)$, the glassy carbon electrode (GCE) $(3,7)$, and the pyrolytic graphite electrode (PGE) $(8,9)$, have been described. The platinum electrode (PtE) was a Sargent (S-29414) platinim wire electrode with a surface area of $0.07 \mathrm{~cm}^{2}$.
The $\mathrm{pH}$ values of the solutions were measured using a Beckman Model $\mathrm{H}-2 \mathrm{pH}$ meter and a glass electrode. The $\mathrm{pH}$ was adjusted with perchloric acid or sodium hydroxide.

Reagent: The organic reagents were "Baker" or "Baker Analyzed" except the iminodiacetic acid (City Chemical Corporation, U.S.A.). The other chemicals were reagent grade and prepared in the usual manner. Purified nitrogen was used to deaerate the test solutions.

\section{DISCUSSION}

The solutions were $0.5 \mathrm{M}$ in sodium perchlorate and contained the organic ligand at various $\mathrm{pH}$ values. The solutions were electrolyzed at the stationary electrode using a starting potential of 1.500 volts versus the saturated calomel electrode. The scan rate was $300 \mathrm{mV} / \mathrm{min}$.

The effects of selected organic materials on the usuable potential range are shown in Table I. The organic materials that were chosen are to be used in the investigation of the voltammetry of the neptunium(VI) and plutonium(VI) complexes at the glassy carbon electrode and the pyrolytic graphite electrode. Each organic had a different effect on each electrode function. An exception to this, however, is the malonate ion which had the same effect on each electrode function, $29 \mathrm{mV} / \mathrm{pH}$. At the other extreme, the electrode function of the GCE in the presence of the succinate ion is $62 \mathrm{mV} / \mathrm{pH}$ whereas the electrode function of the $\mathrm{PGE}$ is $14 \mathrm{mV} / \mathrm{pH}$.

These data will be an aid in selecting the proper electrode for the investigation to be. performed.

\section{REFERENCES}

1. A. L. Beilby, W. Brooks, Jr., and G. L. Lawrence, Anal. Chem., 36, 22 (1964).

2. H. E. Zittel and F. J. Miller, Anal. Chem., 37, 200 (1965).

3. C. E. Plock, J. Inorg. Nucl. Chem., in press. 
Table I. Effect of pH and ligand on potential ranges of the glassy carbon, pyrolytic graphite, and platinum wire electrodes.

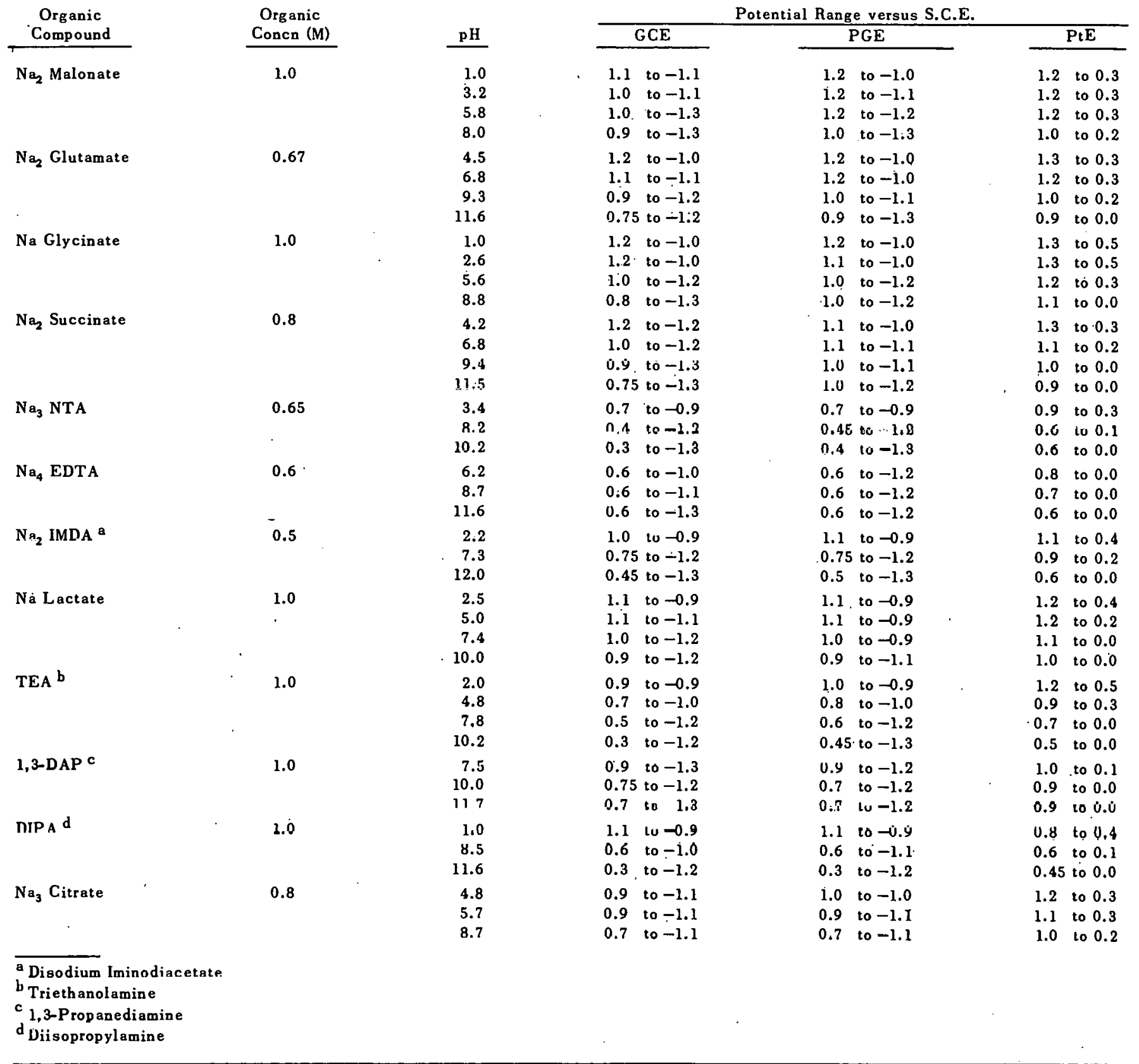

4. C. E. Plock, Anal. Chim. Acta, in press.

5. C. E. Plock, "Voltammetric Investigation of the Neptunyl Glycinate Complex at the Rotated Glassy Carbon Electrode," Rocky Flats Division, The Dow Chemical Company, unpublished data, 1968.

6. C. E. Plock, "Voltammetric Behavior of Neptunium(VI) Succinate Complex at the Rotating Pyrolytic Graphite Electrode," Rocky
Flats Division, The Dow Chemical Company, unpublished data, 1968.

7. C. E. Plock, J. Electroanal. Chem., 18, 289 (1968).

8. F. J. Miller and H. E. Zittel, Anal. Chem., 35 1866 (1963).

9. T. M. Florence, F. J. Miller, and H. E. Zittel, Anal. Chem., 38, 1065 (1966). 